\title{
Isolation of entomopathogenic nematodes in the west region of Santa Catarina, Brazil
}

\author{
Isolamento de nematoides entomopatogênicos \\ na região oeste de Santa Catarina, Brasil
}

\author{
Dannyelle Cristine Orsolin de Morais ${ }^{1}$ (1) (orcid.org/0000-0003-4990-0571) \\ Marco Aurélio Tramontin 1* (1) (orcid.org/0000-0002-3888-8696) \\ Vanessa Andaló ${ }^{2}$ (1) (orcid.org/0000-0002-6310-1680)
}

\begin{abstract}
Entomopathogenic nematodes (EPNs) are potential candidate for integrated pest management programs. As little is known about the presence of these organisms in the state of Santa Catarina, it was aimed to perform soil sampling in the cities of Chapecó, Palmitos, Seara and Concordia for the isolation of EPNs. In total, 200 samples (100 g soil) were collected. In Chapecó, 40 samples from soil containing green manure (Raphanus sativus), five samples from native forest area and five samples from riparian forest were collected. In the city of Palmitos, 40 soil samples were obtained in the areas of soybean (Glycine max), corn (Zea mays), oats (Avena strigosa), and pasture (Pennisetum purpureum), and in each location 10 samples were taken. Sixty soil samples were collected in the city of Concordia, in a pasture area (A. strigosa). In Seara, the 50 soil samples were collected at a pasture consortium site between ryegrass (Lolium multiflorum) and black oats (A. strigosa). For the isolation, the collected soil samples were conditioned in $350 \mathrm{~mL}$ plastic containers and sent to the laboratory of the university. Later, four larvae of Tenebrio molitor of last instar were inserted, and the sets were maintained at the temperature of $25^{\circ} \mathrm{C}$ for seven days. After this period, the presence of dead larvae was verified, and the confirmation of the mortality by EPNs was evaluated using of White's trap. The positive samples for EPNs were obtained from the cities of Chapecó and Concordia, which corresponded to 2\% of the total soil samples.
\end{abstract}

KEYWORDS: Nematoda; integrated pest management; biological control.
RESUMO: Os nematoides entomopatogênicos (NEPs) apresentam potencial para utilização em programas de manejo integrado de pragas. Como pouco se conhece sobre a presença desses organismos no estado de Santa Catarina, objetivou-se realizar amostragens de solo nas cidades de Chapecó, Palmitos, Seara e Concórdia para o isolamento de NEPs. No total foram coletadas 200 amostras (100 g solo). Em Chapecó, foram coletadas 40 amostras em solo contendo adubo verde (Raphanus sativus), cinco amostras de área de floresta nativa e cinco amostras de mata ciliar. Em Palmitos, foram obtidas dez amostras em cada área, totalizando 40. Foram elas: soja (Glycine max), milho (Zea mays), aveia (Avena strigosa) e pastagem (Pennisetum purpureum). Realizaram-se 60 amostras de solo na cidade de Concórdia, em área de pastagem (A. strigosa). Em Seara, as 50 amostras de solo foram retiradas em um local de consórcio de pastagem entre azevém (Lolium multiflorum) e aveia preta (A. strigosa). Para o isolamento, as amostras de solo coletadas foram acondicionadas em recipientes plásticos de $350 \mathrm{~mL}$ e alocadas no laboratório da universidade. Foram posteriormente inseridas quatro larvas de Tenebrio molitor de último instar, e mantiveram-se os conjuntos em temperatura de $25^{\circ} \mathrm{C}$ por sete dias. Após esse período, verificou-se a presença de larvas mortas, e a confirmação da mortalidade por NEP foi feita por meio de armadilha de White. As amostras positivas para NEPs foram obtidas da cidade de Chapecó (População 7, 18, 26) e Concórdia (População Concórdia), o que correspondeu a $2 \%$ do total de amostras de solo.

PALAVRAS-CHAVE: Nematoda; manejo integrado de pragas; controle biológico.

\footnotetext{
'Universidade Federal da Fronteira Sul - Chapecó (SC), Brazil

2Universidade Federal de Uberlândia - Monte Carmelo (MG), Brazil

*Corresponding author: marco.silva@uffs.edu.br

Received on: 04/28/2019. Accepted on: 05/15/2020
} 
The entomopathogenic nematodes (EPNs) are associated with symbiotic bacteria, and after penetration into the host insect the release of these symbionts causes mortality of the target within 72 hours after infection (FERRAZ et al., 2008; DILLMAN et al., 2012). EPNs have a potential as biological control agents since these organisms have a wide range of geographic areas, soil types and are adapted to several hosts. They do not cause damage to the environment and may also have synergistic effect with some phytosanitary products (GREWAL, 2012; LACEY, 2015; KAPRANAS et al., 2017).

In addition to the potential of these entomopathogens to control insects, studies have been developed to isolate these microorganisms from the soil and to perform pathogenicity tests on insects of agricultural importance (LU et al., 2016). Soil samples and isolation of EPNs in Brazil were made in the states of Minas Gerais (ACEVEDO et al., 2005; ANDALÓ et al., 2018), Rondônia (DOLINSKI; MOINO, 2006), Rio Grande do Sul (BARBOSA-NEGRISOLI et al., 2010; FOELKEL et al., 2017), São Paulo and Paraná (DE BRIDA et al., 2017).

In the agroecosystem, EPNs are affected by soil properties such as soil texture, moisture, temperature and organic matter, which might be drastically altered by agricultural management practices, such as crop rotation and cover crop rotation (JAFFUEL et al., 2016).

In the state of Minas Gerais, the natural populations of Heterorhabditis amazonensis were found in cerrado and gallery forest areas (ANDALÓ et al., 2018). In the state of Rio Grande do Sul, the occurrence of the species Steinernema feltiae, Steinernema rarum and Steinernema riobrave was reported for the first time in Brazil (BARBOSA-NEGRISOLI et al., 2010). Nematodes of the genera Oscheius are found in apple orchard (FOELKEL et al., 2017). EPNs also identified in agricultural areas of Sáo Paulo and Paraná were $H$. amazonensis, Metarhabditis rainai, Oscheios tipulae and $S$. rarum (DE BRIDA et al., 2017).

In places where these microorganisms have not yet been explored, studies for sampling and isolation of EPNs are necessary (ACEVEDO et al., 2005). When EPNs are locally adapted, they provide effective control compared to exotic species (LU et al., 2016; RIVERA et al., 2016). Therefore, this study aimed to isolate EPNs in different agricultural areas of the west region of Santa Catarina, Brazil.

For the isolation of EPNs, surveys were conducted obtaining soil sampling from the cities of Chapecó, Palmitos, Seara and Concórdia between April and June 2017. According to Köppen's classification, the climate of the region is $\mathrm{Cfa}$, with average annual temperature of $20^{\circ} \mathrm{C}$ and annual average rainfall of $1,830 \mathrm{~mm}$ (UHLMANN et al., 2012). The red clay latosol soil is predominant of western region of Santa Catarina state (POTTER et al., 2004).

Samples were collected from $10-\mathrm{cm}$ depth from the soil surface, with the aid of a garden shovel, and the difference between each collection was at least $1 \mathrm{~m}$ apart. At each point of sampling, about $100 \mathrm{~g}$ of soil was collected, packed in plastic bags and transported to the laboratory in styrofoam box.

In Chapecó, 40 samples were collected in a revolved soil, containing previously Raphanus sativus, five samples in native forest area and five samples in riparian forest. In Palmitos, there were 10 samples in each area with annual crops: soybean (Glycine max), corn (Zea mays), oats (Avena strigosa) and pasture (Pennisetum purpureum), generating 40 samples. Sixty soil samples were collected in the city of Concórdia, in a pasture area $(A$. strigosa). In Seara, the 50 soil samples consisted of a pasture consortium between ryegrass (Lolium multiflorum) and black oats (A. strigosa). These collections totaled 200 soil samples (Fig. 1).

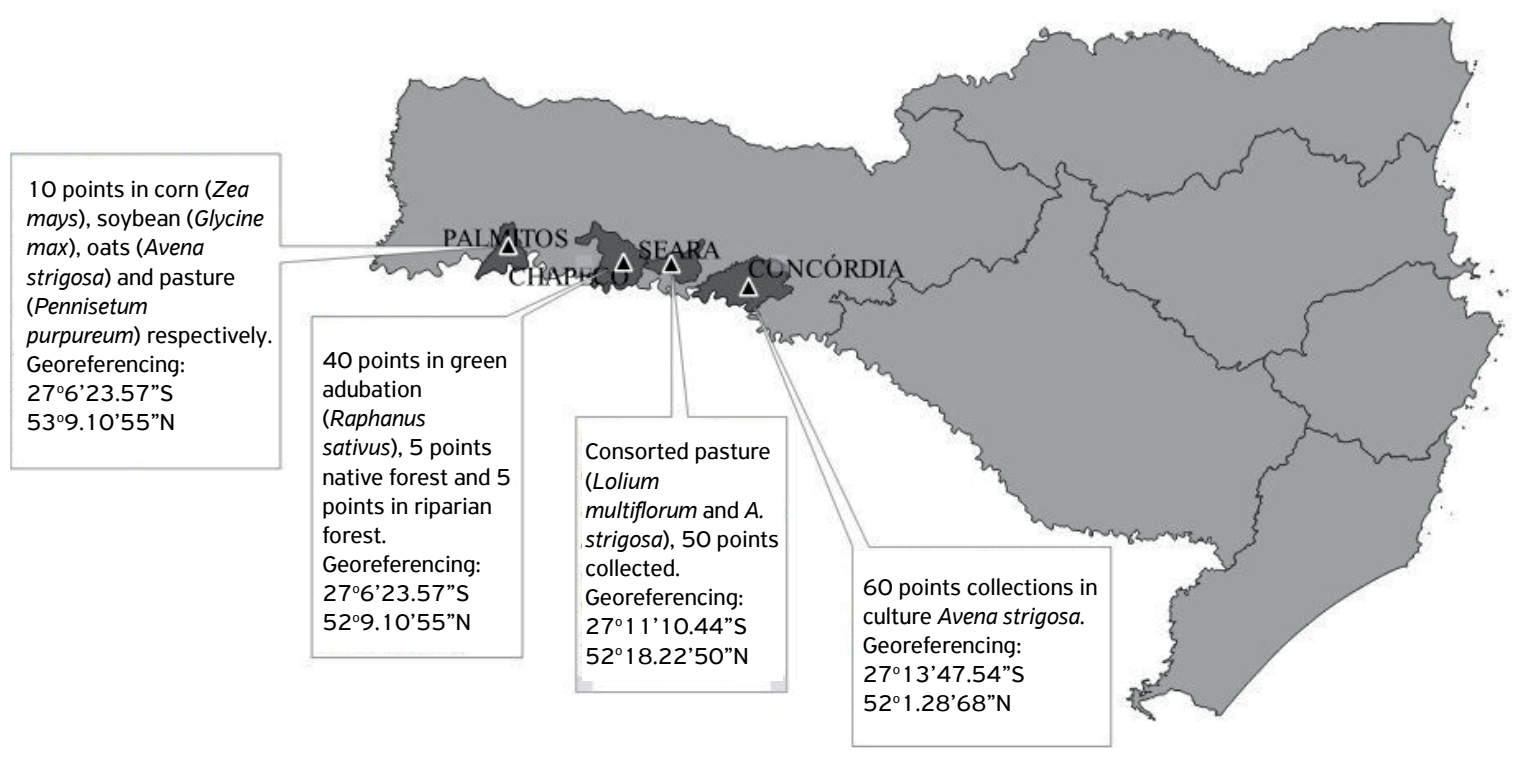

Source: QGIS DEVELOPMENT TEAM (2019).

Figure 1. Cities of Santa Catarina State where soil samples were collected for the isolation of entomopathogenic nematodes. 
The insect-trap technique was used to obtain the EPNs. The soil samples were conditioned in plastic containers $(9 \times 12 \mathrm{~cm})$ containing $100 \mathrm{~g}$ of soil and moistened with distilled water (when necessary). After that, four larvae of Tenebrio molitor L. (Coleoptera: Tenebrionidae) of last instar were added to each container, and all of them were closed with voil (BEDDING; AKHURST, 1975). The plastic containers were kept at the temperature of $25 \pm 20^{\circ} \mathrm{C}$ in the Laboratory of Botany, Ecology and Entomology of Universidade Federal de Fronteira Sul.

Later, the dead larvae were transferred to a white trap at $25 \pm 2^{\circ} \mathrm{C}$ for ten days. The infective juveniles (IJs) that left the T. molitor carcasses were collected daily with distilled water and stored at $18 \pm 2^{\circ} \mathrm{C}$. To purify and confirm the parasitism, Koch's postulates were applied by multiplications in larvae of T. molitor. The larvae of $T$. molitor were raised according to the methodology of POTRICH et al. (2007).

The cities that presented positive samples for EPNs were Chapecó and Concórdia. From the soil samples from Chapecó, three samples were positive to EPNs, obtaining three isolates Population 7, Population 18 and Population 26 - from a total of $40(7.5 \%)$ (Table 1$)$. From the samples collected in the city of Concórdia, only one sample presented EPN, which corresponded to $1.6 \%$ of the total of 60 samples taken at the area (Table 1). The isolate captured at this site was called Population Concórdia.

In relation to the positive samples obtained, there are several favorable conditions that may have benefited the occurrence of EPNs in these areas, such as moisture, organic matter and associated cultures that favor the establishment of EPNs (LEWIS et al., 2015). Although these parameters were not directly compared in this study, soil samples positive for EPNs have clayey texture (POTTER et al., 2004).

The soils from the cities of Chapecó and Concórdia where EPNs were found are classified according to Brazilian Soil Classification System (SIBCs) as latosoil (EMBRAPA, 2013). These soils have as characteristics the silt content less than $20 \%$ and clay varying between 15 to $80 \%$, and they are strongly to well drained (EMBRAPA, 2013). The clay texture did not interfere in the survival of EPNs, as reported by BARBERCHECK; KAYA (1991). Instead, each type of soil has a variety of unique characteristics that may have different effects on EPNs species (SHAPIRO et al., 2000).

In this study, it was observed that the cambisoils have medium or fine texture, while the argisoils can be sandy and have medium to clayey texture, and the nitosols are characterized by clayey to very clayey texture. However, these three soils have the common characteristic of good drainage. Anyway, organosoils come from predominantly organic material and are commonly associated with poorly drained environments, in which case the availability of oxygen may be difficult (EMBRAPA, 2013).

The soil texture can also influence the efficacy of the nematode. As the clay content increases, the nematode dispersion and the survival are influenced (SHAPIRO et al., 2000; KOPPENHOFER; FUZY, 2006). The moisture is one of the major factors affecting survival, virulence and persistence of IJs in the soil (LU et al., 2016), and different ranges of soil moisture affect the EPNs to find and infect a host (ACEVEDO; NÚNEEZ, 2003; SALAME; GLAZER, 2015).

In addition, optimum moisture levels will vary by nematode species and soil type, since excess moisture can cause oxygen deprivation and restrict movement. Soil characteristics must also be considered (SHAPIRO et al., 2006), as already mentioned in the soil texture. Studies generally report that lighter soils and soils with higher clay content restrict nematode movement and have reduced aeration potential, which may result in less nematode survival (GEORGIS; POINAR, 1983; MOLYNEUX; BEDDING, 1984). However, exceptions have been observed (SHAPIRO et al., 2000), and this study proved the occurrence of EPNs in soils with clayey texture (latosoil).

Table 1. Relationship of collection sites and positive samples for entomopathogenic nematodes.

\begin{tabular}{|c|c|c|c|c|c|}
\hline Collection Location & City & $\begin{array}{l}\text { Total number } \\
\text { of collections }\end{array}$ & $\begin{array}{l}\text { Number of positive } \\
\text { samples for EPNs }\end{array}$ & $\begin{array}{l}\text { Percentage of positive } \\
\text { samples for EPNs (\%) }\end{array}$ & Soil type \\
\hline Green adubation (Raphanus sativus) & Chapecó & 40 & 3 & 7,5 & Latosoil \\
\hline Native forestin & Chapecó & 5 & - & - & Organosoil \\
\hline Riparian forest & Chapecó & 5 & - & - & Nitosoil \\
\hline Corn (Zea mays) & Palmitos & 10 & - & - & Argisoil \\
\hline Soybean (Glycine max) & Palmitos & 10 & - & - & Argisoil \\
\hline Oats (Avena strigosa) & Palmitos & 10 & - & - & Argisoil \\
\hline Pasture (Pennisetum purpureum) & Palmitos & 10 & - & - & Argisoil \\
\hline Pasture (Avena strigosa) & Concórdia & 60 & 1 & 1,6 & Latosoil \\
\hline $\begin{array}{l}\text { Consorted pasture } \\
\text { (Lolium multiflorum and A. strigosa) }\end{array}$ & Seara & 50 & - & - & Cambisoil \\
\hline Total & & 200 & 4 & 2 & \\
\hline
\end{tabular}

EPNs: entomopathogenic nematodes. 
Several studies have demonstrated negative effects of intensive soil management (chemical fertilization, agrochemicals, monoculture, harrowing, among others) on EPNs (CAMPOSHERRERA et al., 2012; CAMPOS-HERRERA et al., 2014; JAFFUEL et al., 2016). Though, the EPN populations isolated in the present study were found in agricultural areas. This fact can be justified by the adoption of smaller quantities of plant protection products, better vegetation cover on the soil and less soil rotation in the isolation areas when compared to soybean areas and corn.

The cultures to be implemented, as well as the history of the area (crop rotation), have an important effect on the abundance and activity of EPNs (JAFFUEL et al., 2016). In this study, the consortium of pastures favored greater root activity in the soil profile, such as nutrient recycling in the soil provided by $R$. sativus.

In a study of native EPN, $15.70 \%$ of the samples from the state of Rio Grande do Sul from the set of 121 soil samples collected contained EPNs. For the EPN positive samples, 7.69 to $18.18 \%$ were observed in forests, native pastures, fruit trees and corn, and between 21.42 and $25 \%$ were identified in soybean and tobacco. The species identified were $S$. rarum, Heterorhabditis bacteriophora, $H$. amazonensis, S. feltiae, Steinernema glaseri and S. riobrave (BARBOSA-NEGRISOLI et al., 2010).

In a verification survey of EPNs in the state of Minas Gerais, a total of 216 soil samplings was performed, from which three populations of EPNs were identified as $H$. amazonensis - two populations found in the cerrado area and one in the gallery forest (forest that forms corridor along rivers). Both areas are characterized by the presence of high-density vegetation cover, due to the characteristics associated with these biomes (ANDALÓ et al., 2018).
In a study investigating the presence of EPNs in the cities of Barretos, Botucatu, Garça, São Manuel, São Paulo, and Palotina, Paraná, samples were taken of agricultural soils with annual, fruit and forest crops, totaling 201 samples. From this total, 16 samples presented EPNs, which corresponded to $8 \%$. Areas with positive samples were forest plantations (seven samples), annual crops (three samples) and orchards (six samples). The species identified were $H$. amazonensis, $M$. rainai, $O$. tipulae and $S$. rarum. EPNs samples were not found in plowed soil, native forest nor pasture areas. This result may also indicate the need for a higher number of samples collected at different soil depths (DE BRIDA et al., 2017). It demonstrates the difficulty in obtaining positive samples, even when they are collected in different environments.

This study did not present positive samples for EPNs in native forest nor in agricultural crops such as maize, which differs from the positive samples for EPNs found in other studies in Brazil (BARBOSA-NEGRISOLI et al., 2010; ANDALÓ et al., 2018; DE BRIDA et al., 2017). However, this study presented positive samples in pasture and soil areas with green manure, and it corroborates with BARBOSA-NEGRISOLI et al. (2010) and differs from the results presented by DE BRIDA et al. (2017).

The variation of sites with or without EPNs requires a great deal of effort mainly in sampling (sample area, number of samples, sample size), as well as the combination of extraction techniques of these soil microorganisms to avoid losses during the isolation of these entomopathogens (BARBOSA-NEGRISOLI et al., 2010; DE BRIDA et al., 2017). The isolation of the three populations in the west of Santa Catarina demonstrates the wide distribution of these organisms in Brazil, besides the potential use in pest control in the region, because they are adapted to the local conditions.

\section{ACKNOWLEDGEMENTS: Not applicable.}

FUNDING: This work did not receive any specific grant from funding agencies in the public, commercial, or not-for-profit sectors.

CONFLICTS OF INTEREST: The authors certify that they have no commercial or associative interest that represents a conflict of interest in connection with the manuscript.

ETHICAL APPROVAL: Not applicable.

AVAILABILITY OF DATA AND MATERIAL: All data generated or analyzed during this study are included in this published article.

AUTHORS' CONTRIBUTIONS: Conceptualization: Tramontin, M.A; Ándalo, V. Visualization, Writing - original draft: Orsolin, D.C.M. Writing - review \& editing: Tramontin, M.A; Ándalo, V.

\section{REFERENCES}

ACEVEDO, J.P.M.; NÚÑEZ, J.C.L. Supervivencia y parasitismo de nematodos entomopatógenos para el control de Hypothenemus hampei, (Coleoptera: Scolytidae) en frutos de café. Boletín Sanidad Vegetal de Plagas, v.29, n.4, p.523-533, 2003.
ACEVEDO, J.P.M.; MOINO, A.J.; CAVALCANTI, R.S.; DOLINSKI, C.; CARVALHO, F.A. Amostragem e avaliação de técnicas para isolamento de nematóides entomopatogênicos nativos obtidos em Lavras, Minas Gerais. Nematologia Brasileira, v.29, n. 1, p.17-23, 2005. 
ANDALÓ, V.; MIEKO, J.; CARVALHO, F.J.; DE ASSIS, G.A.; DE FARIA, L.S.; DE ASSIS, F.A.; ROSA, F. Entomopathogenic nematode distribution and edaphoclimatic conditions in the Cerrado of Minas Gerais, Brazil. Applied Entomology and Zoology, v.53, n. 1, p. $129-$ 136, 2018. https://doi.org/10.1007/s13355-017-0538-4

BARBERCHECK, M.E.; KAYA, H.K. Effect of host condition and soil texture on host finding by the entomogenous nematodes Heterorhabditis bacteriophora (Rhabditida: Heterorhabditidae) and Steinernema carpocapsae (Rhabditida: Steinernematidae). Environmental Entomology, v.20, n.2, p.582-589, 1991. https:// doi.org/10.1093/ee/20.2.582

BARBOSA-NEGRISOLI, C.R.B.; GARCIA, M.S.; DOLINSKI, C.; NEGRISOLI, J.R.A.S.; BERNARDI, D.; DOS SANTOS, F.J. Survey of entomopathogenic nematodes (Rhabditida: Heterorhabditidae, Steinernematidae) in Rio Grande do Sul State, Brazil. Nematologia Brasileira, v.34, n.4, p.189-197, 2010.

BEDDING, R.A.; AKHURST, R.J. A simple technique for the detection of insect parasitic rhabditid nematodes in soil. Nematologica, v.21, n. 1, p.109-110, 1975. 10.1163/187529275X00419

CAMPOS-HERRERA, R.; EL-BORAI, F.E.; DUNCAN, L.W. Wide interguild relationships among entomopathogenic and free-living nematodes in soil as measured by real time qPCR. Journal of Invertebrate Pathology, v.111, n.2, p.126-135, 2012. https:// doi.org/10.1016/j.jip.2012.07.006

CAMPOS-HERRERA, R.; EL-BORAI, F.E.; EBERT, T.E.; SCHUMANN, A.; DUNCAN, L.W. Management to control citrus greening alters the soil food web and severity of a pest-disease complex. Biological Control, v.76, p.41-51, 2014. https://doi.org/10.1016/j. biocontrol.2014.04.012

DE BRIDA, A.L.; ROSA, J.M.O.; DE OLIVEIRA, C.M.G.; CASTRO, B.M.D.C.; SERRÃO, J.E.; ZANUNCIO, J.C.; GARRIGÓS, L.L.; WILCKEN, S.R.S. Entomopathogenic nematodes in agricultural areas in Brazil. Scientific Reports, v.7, p.45254, 2017. https:// doi.org/10.1038/srep45254

DILLMAN, A.R.; CHASTON, J.M.; ADAMS, B.J.; CICHE, T.A.; GOODRICH-BLAIR, H.; STOCK, S.P.; STERNBERG, P.W. An entomopathogenic nematode by any other name. PLoS Pathogens, v.8, n.3, p.e 1002527, 2012. https://doi.org/10.1371/journal. ppat. 1002527

DOLINSKI, C.; MOINO J.R.A. Utilização de nematóides entomopatogênicos nativos ou exóticos: o perigo das introduções. Nematologia Brasileira, v.30, n.2, p.139-149, 2006.

EMPRESA BRASILEIRA DE PESQUISA AGROPECUÁRIA (EMBRAPA). Sistema Brasileiro de Classificação dos Solos (SIBCS). Brasília: EMBRAPA-SPI, Centro Nacional de Pesquisa de Solos, 2013.

FERRAZ, L.C.C.B.; LEITE, L.G.; LOPES, R.B.; MOINO, J.R.A.; DOLINSKI, C. Utilização de nematóides para o controle de pragas agrícolas e urbanas. In: Alves, S.B.; Lopes, R.B. Controle microbiano de pragas na América Latina: avanços e desafios. Piracicaba: FEALQ, 2008. p.171-202.

FOELKEL, E.; VOSS, M.; MONTEIRO, L.B.; NISHIMURA, G. Isolation of entomopathogenic nematodes in an apple orchard in Southern
Brazil and its virulence to Anastrepha fraterculus (Diptera: Tephritidae) larvae, under laboratory conditions. Brazilian Journal of Biology, v.77, n.1, p.22-28, 2017. https://doi. org/10.1590/1519-6984.08315

GEORGIS, G.O.; POINAR, J.R. Effect of soil texture on the distribution and infectivity of Neoaplectana carpocapsae (Nematoda: Steinernematidae). Journal of Nematology, v.15, n.2, p.308-311, 1983.

GREWAL, P.S. Entomopathogenic nematodes as tools in integrated pest management. Integrated pest management: principles and practice. Wallingford, UK: Cabi Publishing, 2012. p.162-236.

JAFFUEL, G.; MÄDER, P.; BLANCO-PEREZ, R.; CHIRIBOGA, X.; FLIESSBACH, A.; TURLINGS, T.C.; CAMPOS-HERRERA, R. Prevalence and activity of entomopathogenic nematodes and their antagonists in soils that are subject to different agricultural practices. Agriculture, Ecosystems \& Environment, v.230, p.329-340, 2016. https://doi.org/10.1016/j.agee.2016.06.009

KAPRANAS, A.; MALONE, B.; QUINN, S.; MCNAMARA, L.; WILLIAMS, C.D.; O'TUAMA, P.; PETERS, A.; GRIFFIN, C.T. Efficacy of entomopathogenic nematodes for control of large pine weevil Hylobius abietis: effects of soil type, pest density and spatial distribution. Journal of Pest Science, v.90, n.2, p.495-505, 2017. https://doi.org/10.1007/s10340-016-0823-y

KOPPENHOFER, A.M.; FUZY, E.M. Effect of soil type on infectivity and persistence of the EPNs Steinernema scarabaei, Steinernema glaseri, Heterorhabditis zealandica, and Heterorhabditis bacteriophora. Journal of Invertebrate Pathology, v.92, n. 1, p.11-22, 2006. https://doi.org/10.1016/j.jip.2006.02.003

LACEY, L.A.; GRZYWACZ, D.; SHAPIRO-ILAN, D.I.; FRUTOS, R.; BROWNBRIDGE, M.; GOETTEL, M.S. Insect pathogens as biological control agents: back to the future. Journal of Invertebrate Pathology, v.132, p.1-41, 2015. https://doi.org/10.1016/j. jip.2015.07.009

LEWIS, E.E.; HAZIR, S.; HODSON, A.; GULCU, B. Trophic relationships of entomopathogenic nematodes in agricultural habitats. In: CAMPOSHERRERA, R. (Ed.). Nematode pathogenesis of insects and other pests. Sustainability in plant and crop protection. Cham: Springer, 2015. https://doi.org/10.1007/978-3-319-18266-7_5

LU, D.; BAIOCCHI, T.; DILLMAN, A.R. Genomics of entomopathogenic nematodes and implications for pest control. Trends in Parasitology, v.32, n.8, p.588-598, 2016. https://doi.org/10.1016/j. pt.2016.04.008

MOLYNEUX, A.S.; BEDDING, R.A. Influence of soil texture and moisture on the infectivity of Heterorhabditis sp. D 1 and Steinernema glaseri for larvae of the sheep blowfly Lucilia cuprina. Nematologica, v.30, n.3, p.358-365, 1984. https:// doi.org/10.1163/187529284X00266

POTTER, R.O.; CARVALHO, A.P.; FLORES, C.A.; BOGNOLA, I. Solos do Estado de Santa Catarina. Embrapa Solos-Boletim de Pesquisa e Desenvolvimento (INFOTECA-E). 2004. Available from: https://www.infoteca.cnptia.embrapa.br/bitstream/ doc/964417/1/BPD462004SantaCatarina.pdf. Access on: Apr. 232019. 
POTRICH, T.D.; LORINI, I.; VOSS, M.; STEFFENS, M.C.S.; PAVANI, D.P. Methodology to rear Tenebrio molitor in laboratory to obtain larvae. Passo Fundo: Embrapa Trigo, 2007.

QGIS Development Team. QGIS Geographic Information System. Open Source Geospatial Foundation Project 2019. Available from: http://qgis.osgeo.org. Access on: May 25, 2019.

RIVERA, M.J.; RODRIGUEZ-SAONA, C.; EGIZI, A.; FONSECA, D.M.; JENNINGS, D.E.; KOPPENHÖFER, A.M. Cultivation and domestication of highbush blueberry (Vaccinium corymbosum) alters abundance, diversity and virulence of entomopathogenic nematodes. Agriculture, Ecosystems \& Environment, v.222, p. 148155, 2016. https://doi.org/10.1016/j.agee.2016.02.013

SALAME, L.; GLAZER, I. Stress avoidance: vertical movement of entomopathogenic nematodes in response to soil moisture gradient. Phytoparasitica, v.43, n.5, p.647-655, 2015. https:// doi.org/10.1007/s12600-015-0488-8
SHAPIRO, D.I.; MCCOY, C.W.; FARES, A.; OBREZA, T.; $\mathrm{DOU}, \mathrm{H}$. Effects of soil type on virulence and persistence of entomopathogenic nematodes in relation to control of Diaprepes abbreviatus (Coleoptera: Curculionidae). Environmental Entomology, v.29, n.5, p.1083-1087, 2000. https://doi. org/10.1603/0046-225X-29.5.1083

SHAPIRO, D.I.; GOUGE, D.H.; PIGGOTT, S.; FIFE, J.P. Application technology and environmental considerations for use of entomopathogenic nematodes in biological control. Biological Control, v.38, n. 1, p.124-133. 2006. https://doi.org/10.1016/j. biocontrol.2005.09.005

UHLMANN, A.; GASPER, A.L.; SEVEGNANI, L.; VIBRANS, A.C.; MEYER, L.; LINGNER, D.V. Fitogeografia de Santa Catarina. In: VIBRANS, A.C.; SEVEGNANI, L.; GASPER, A.L.; LINGNER, D.V. (Eds.). Inventário florístico florestal de Santa Catarina. Blumenau: EDIFURB, 2012. v. 1.p. 113-123. 